\title{
TELAAH DEKONSTRUKSI KEKUASAAN DALAM NOVEL DARI FONTENAY KE MAGALLIANES KARYA NH. DINI DALAM PERSPEKTIF BUDAYA
}

\author{
oleh Sugiarti \\ FKIP Universitas Muhammadiyah Malang
}

\begin{abstract}
This article concerns a study whose objective is to explain several issues related to (1) a description of the domination, hegemony, and subordination of characters in a novel, (2) the function of the power culture experienced by the characters, and (3) the meaning of power deconstruction in the novel.

To reach the objective, the researcher conducting the study employs a qualitative-descriptive method. The source of data is the novel Dari Fontenay ke Magallianes by Nh. Dini. The data are in the form of extracts taken from the novel and, complemented with the researcher's thoughts pertaining to issues related to society and power, collected through documentation and literary study with thorough understanding. Data validity is confirmed by employing a series of such techniques as (1) careful observation, (2) adequate literary reference, (3) peer discussion among parties sharing interest in literary works, and (4) triangulation by searching available articles for related information about the novelist concerned.

The results of the study show the following. (1) The types of power described in the novel are greatly reflected in the behavior of a character's husband toward his family (wife and children) and his colleagues. The power types could be exposed through the husband's attitude, ideology, and behavior in response to the surrounding environment as part of his community. (2) The power culture functions to provide some characters with experiences suggesting that some social issues have to be overcome by way of different unsatisfactory treatments. In addition, the power functions as a "bond" that makes someone obey what is instructed by the one who is in power. (3) An analysis on the meaning of the power manifested in the text through female characters shows that it is a kind of counterdiscourse against the hegemony of the central power.
\end{abstract}

Keywords: current thought movement, new perspective

\section{A. PENDAHULUAN}

Sastra tidak dapat dilepaskan dengan fenomena yang terjadi dalam masyarakat. Permasalahan yang diungkap dalam sastra sebagian merupakan masalah sosial, misalnya terkait dengan hubungan manusia dengan manusia serta kebudayaan yang melingkupinya.
Karya sastra yang berbobot merupakan produk strukturasi dari subjek kolektif (subjek sosial historis). Oleh karena itu, sastra mempunyai struktur yang bersatu padu mengenai hubungan manusia dengan sesamanya dan alam serta zamannya. Menurut Goldman (dalam Faruk 1999: 17) sastra merupakan ekspresi pandangan dunia imajiner, 
dalam usaha mengekpresikan pandangan dunia..

Sastra mengungkapkan berbagai persoalan sosial yang terjadi dalam masyarakat, misalnya relasi laki-laki dan perempuan. Pada kenyataannya perempuan di dalam kehidupan sosial selalu dinilai sebagai the other sex yang sangat menentukan mode representasi sosial tentang status dan peran perempuan (Abdullah, 1997: 3). Sebaliknya, Teeuw (1984) mengatakan bahwa karya sastra tidak dapat lepas dari pengarang dalam masyarakatnya, karena karya sastra tidak hadir dalam kekosongan budaya. Karya sastra tidak dapat dilepas dari pengarang yang menulisnya. Pengarang tidak lepas dari pikiran/pandangan dunia dan perkembangan zaman.

Interpretasi pengarang terhadap realitas kehidupan menghasilkan konstruksi sosial, baik relasi antara laki-laki dan perempuan maupun antara berbagai perlakuan serta representasi kekuasaan yang menyertainya. Selama ini konstruksi sosial yang telah terjadi dalam kehidupan sosial banyak merugikan salah satu pihak (terutama perempuan). Seiring dengan perkembangan zaman dan meluasnya kajian sastra dalam perspektif budaya (postmodernisme) tidak mengherankan jika masalah sosial yang terdapat dalam karya sastra menarik untuk dijadikan bahan kajian. Hal ini sejalan dengan pemikiran Jabrohim (2001: 167) yang mengatakan bahwa pengarang, penyair, atau seniman umumnya itu senantiasa dan niscaya hidup dalam ruang dan waktu tertentu. Pengarang akan senantiasa terlibat dengan beraneka ragam permasalahan. Bentuk paling nyata adalah masyarakat atau kondisi sosial tempat berbagai pranata nilai yang berinteraksi. Dalam konteks ini sastra bukanlah sesuatu yang otonom, melainkan sesuatu yang terikat erat dengan situasi dan kondisi lingkungan tempat karya sastra itu dilahirkan.

Pada dasarnya pengarang sebagai pencipta karya sastra dalam kehidupannya tidak dapat dilepaskan dari berbagai persoalan yang ada di sekitarnya maupun pemikiranpemikiran yang menjadi keyakinan dirinya.
Dalam banyak hal keterikatan pengarang dengan berbagai persoalan sosial menjadikan inspirasi baru untuk membentuk sebuah pemikiran baru tentang konstruksi sosial yang terdapat dalam karya sastra. Kenyataan yang tidak dapat dihindari adalah bahwa keyakinan pengarang terhadap pandangan dunianya secara implisit akan mewarnai proses penciptaan karya sastra. Dalam hal ini, dekonstruksi kekuasaan antartokoh dalam teks sastra tidak dapat dielakkan. Pada posisi inilah teks sastra relevan untuk dijadikan kajian dalam analisis.

Di samping itu, untuk melakukan analisis secara mendalam diperlukan pendekatan yang dikembangkan Linton (dalam Ratna, 2005: 121) yang disebut istilah bentuk, fungsi, dan makna. Kerangka kerja, bentuk, fungsi, makna memprasyaratkan cara kerja atas dasar kontinuitas, pengamatan mulai dari aspek-aspek yang paling sederhana menuju ke tingkat yang lebih kompleks dan seterusnya.

Adapun permasalahan dalam penelitian ini mencakup: (1) seperti apakah bentuk penggambaran dominasi, hegemoni, dan subordinasi tokoh yang diungkapkan dalam novel Dari Fontenay ke Magallianes karya Nh. Dini?; (2) apa fungsi budaya kekuasaan yang diungkapkan dalam novel Dari Fontenay ke Magallianes karya Nh. Dini?; serta apa makna dekontruksi kekuasaan dalam novel Dari Fontenay ke Magallianes karya Nh. Dini ?

Secara teoretis manfaat ini akan penelitian ini adalah: (1) memperkaya tema pengkajian teori sosiologi sastra dan teori wacana sastra, (2) memperluas penerapan teori sosiologi di dalam wacana sastra, (3) memperkaya dan memperluas penerapan teori sosial di bidang simbol-simbol budaya khususnya wacana sastra karya NH Dini. (4) mengembangkan konstruksi pengkajian sastra yang berorientasi pada model research fenomenologis atas sastra Indonesia.

Secara praktis, hasil penelitian ini akan memberikan sumbangan berarti karena dapat dimanfaatkan untuk (1) memperoleh informasi tentang dekonstruksi hubungan antara pengarang dengan kekuasaan yang 
direpresentasikan dalam wacana sastra, (2) memperoleh informasi tentang persepsi serta resepsi sastra dan sastrawan tentang kekuasaan, (3) mengetahui hubungan pengarang dengan kekuasaan yang terkait dengan ideologi sosial tertentu, dan (5) mengetahui strategi pembentukan, pelembagaan, pengoperasian, dan pelestarian ideologi sosial tertentu di dalam dunia simbolis yang diciptakan oleh Nh. Dini .

Landasan teori yang digunakan dalam penelitian ini adalah sebagai berikut.

\section{Pascakolonialisme dalam Sastra}

Pascakolonialisme dapat digunakan untuk menelusuri aspek-aspek apa yang tersembunyi atau sengaja disembunyikan sehingga secara tidak langsung dapat diketahui bagaimana kekuasaan itu bekerja. Di pihak apa lain, pendekatan ini digunakan untuk membongkar disiplin, lembaga, dan ideologi yang mendasarinya. Dalam hubungan dengan inilah peranan bahasa, sastra, dan kebudayaan pada umumnya dapat memainkan peranan sebab di dalam ketiga gejala tersebutlah terkandung sebagaimana diintensifkan oleh kelompok kolonialis (Ratna. 2004: 210). Namun demikian, dalam pemahaman visi tradisional karya sastra tidak dapat digunakan sebagai tolak ukur untuk mengetahui perubahan masyarakat tertentu, dan sistem ideologi kelompok tertentu bekerja. Sebaliknya, visi kontemporer menjelaskan bahwa sebagai hasil kreativitas imajinatif karya sastra berhasil untuk melukiskan gejalagejala tersebut. Gejala-gejala tersebut dapat dituturkan melalui cara pandang pascakolonialisme. Menurut Ratna (2004: 212) paling sedikit ada empat alasan mengapa karya sastra dianggap tepat untuk dianalisis melalui teori-tori pasca-kolonial.

(1) sebagai gejala kultural karya sastra menampilkan sistem komunikasi antara pengirim dan penerima ; (2) karya sastra menampilkan berbagai problematika kehidupan emosionalitas dan intelektualitas; (3) karya sastra tidak terikat oleh ruang dan waktu, kotemporaritas adalah manifestasinya yang paling signifikan;
(4) berbagai masalah yang dimaksudkan dilukiskan secara simbolik, dan terselubung sehingga tujuan-tujuan yang sesungguhnya tidak tampak.

Berdasarkan penjelasan tersebut tampak bahwa sastra memiliki keterkaitan langsung dengan berbagai gejala sosial dan budaya yang terjadi di masyarakat. Ia memiliki kekuatan daya imajinatif dan kekreatifannya serta bersifat objektif. Dengan memanfaatkan kekuatan wacana itulah sastra mampu mendekonstruksi kembali narasinarasi yang melibatkan segala aspek lain di luar dirinya, seperti politik, sosial, ekonomi, dan bahkan kebudayaan.

Pada perkembangannya kesusasteraan Indonesia tidak dapat dipungkiri masih diwarnai oleh tradisi-tradisi kolonial yang dikenal sebagai hegemoni kultural. Menurut Said (2003: 44-45) visi pascakolonial menunjukkan bahwa pada masa penjajahan yang ditanamkan adalah perbedaan sehingga jurang pemisah antara kolonial dengan pribumi bertambah lebar. Secara tidak langsung narasinarasi cerita akan dipengaruhi oleh pola pikir dan perilaku penulis dalam mencermati fenomena yang terjadi dalam kehidupan sosial kemasyarakatan.

\section{Wacana Sastra sebagai Konstruksi Kekuasaan}

Dalam pengertian Foucaulttian, wacana merupakan wujud cara manusia membahasakan, mengatakan, dan membicarakan realistis, peristiwa, atau pengalaman dalam dunia-kehidupan manusia (Foucault dalam Said, 2003). Secara linguistis, pembahasan, pengamatan, dan pembicaraan itu sudah membentuk tuturan lengkap dan utuh yang dapat dipahami oleh manusia. Bagi Riceour (1991:43-64), wacana merupakan fiksasi (penghentian) dan stabilisasi (penetapan) realitas, peristiwa, atau pengalaman ke dalam tulisan. Dalam hal ini terjadi pelembagaan realitas, peristiwa, atau pengalaman lisan ke dalam tulisan. Sebagai contoh, peristiwa unjuk rasa menuntut kenaikan 
harga BBM oleh masyarakat dan mahasiswa, serta pengukuran kinerja Kabinet Indonesia Bersatu yang dibahasakan, dikatakan, dan dibicarakan oleh pihak-pihak tertentu merupakan sebuah wacana. Pada tahap ini telah terjadi fiksasi dan stabilitasjuga pelembagaan-- peristiwa dan realitas unjuk rasa dan pemogokan kerja di suatu perusahaan. Menurut Foucault, wacana itu dikerangkai, ditentukan, bahkan dikendalikan oleh episteme atau sistem pemikiran tertentu. Episteme yang dimaksud ialah cara menghayati, merenungi, mengingat, memikirkan, menggagas, dan/atau memandang berbagai realitas, peristiwa atau pengalaman hidup dan kehidupan (Meulleman, 1994). Karena implisit dan kadang-kadang abstrak, wujud episteme dapat diketahui melalui wacana. Oleh sebab itu, wacana menjadi pusat kegiatan manusia dalam menangkap dan membicarakan realitas, peristiwa, atau pengalaman dalam realitas kehidupan.

Sastra khususnya novel dapat dipandang sebagai wacana. Sebagai wacana, sastra (novel) merupakan wujud cara membahasakan, mengatakan, dan membicarakan realitas, peristiwa, atau pengalaman dalam hidup dan kehidupan manusia. Pada saat ini sastra juga telah menjelma menjadi wujud fiksasi dan stabilisasi--- juga pelembagaan--- realitas, peristiwa, atau pengalaman tersebut. Siti Nurbaya dan Layar Terkembang, sebagai contoh, merupakan wacana yang telah membahasakan, mengatakan, dan membicarakan peristiwa dan pengalaman dalam hidup dan kehidupan Minangkabau; tepatnya pengalaman perempuan dalam hidup dan kehidupan Minangkabau. Peristiwa dan pengalaman itu sekaligus mengalami fiksasi dan stabilisasi --- juga pelembagaan --- dalam kedua novel tersebut. Proses ini ikut ditentukan, malah dikendalikan oleh sistem pemikiran tertentu, setidak-tidaknya oleh cara bersikap dan berpikir pengarangnya, yaitu Marah Rusli dan Sutan Takdir Alisyahbana. Oleh sebab itu, peristiwa dan pengalaman hidup dan kehidupan dalam wacana Siti Nurbaya dan Layar
Terkembang tersebut bukan peristiwa dan pengalaman sui generis (asali, hulu, benarbenar terjadi), melainkan peristiwa dan pengalaman yang sudah disofistifikasi dan disignifikasi oleh pengarang menjadi makna atau pengetahuan.

\section{Semiotika dalam Sastra}

Tugas semiotik bukanlah deskripsi tanda-tanda tertentu, melainkan 'to describe those conventions that underlie even the most "natural" modes of behavior and representation" (Culler dalam Teeuw, 1984: 143). Seluruh pengalaman dan kebudayaan manusia berdasarkan tanda, mempunyai dimensi simbolik yang dominan. Semiotika sendiri tidak dapat dilepaskan dari masalahmasalah pokok mengenai tanda (sign), lambang (symbol). Pemahaman masalah lambang akan mencakup masalah pemahaman penanda dan petanda .

Tanda merupakan bagian dari semiotika yang menandai suatu hal atau keadaan untuk menerangkan atau memberitahukan objek kepada subjek. Dalam hal ini tanda selalu menunjukkan pada sesuatu yang nyata, misalnya benda, kejadian, tulisan, bahasa, tindakan, peristiwa, dan bentuk-bentuk tanda yang lain. Contoh: adanya petir selalu ditandai oleh adanya kilat yang mendahului adanya petir tersebut. Wujud tanda alamiah ini merupakan satu bagian dari hubungan secara alamiah pula, yang menunjukkan pada bagian yang lain, yakni adanya petir dikarenakan adanya kilat. Tanda-tanda yang dibuat oleh manusia cenderung menunjukkan pada sesuatu yang terbatas maknanya dan hanya menunjuk hal-hal tertentu.

Sebagai akibat dari kemampuan sastra untuk menjelaskan tanda-tanda, dapat ditentukan ciri-ciri dominan periode tertentu, misalnya pandangan dunia dan ideologi kelompok, jenis hegemoni yang sedang terjadi, dan berbagai kecenderungan lain yang ada dalam masyarakat, yang secara obyektif sulit untuk dideteksi (Ratna. 2004: 112) 


\section{B. METODE PENELITIAN}

Penelitian ini bertujuan untuk mendapatkan pemahamanan yang lengkap tentang struktur, masalah-masalah sosial budaya, dan kekuasaan dalam novel Nh. Dini. Berdasarkan acuan teoretik, penelitian ini menggunakan pendekatan kualitatiffenomenologi, yakni suatu pendekatan dalam studi sastra yang mencoba memahami dan menginterpretasikan fenomena manusia di dalam teks sastra (Lye, 2004:2). Secara lebih operasional, penelitian ini menggunakan prinsip-prinsip metode analisis isi kualitatif yang biasa digunakan untuk memahami pesan simbolik dari wacana atau teks.

Metode penelitian yang digunakan adalah metode deskriptif kualitatif, yakni metode yang berusaha mendeskripsikan suatu gejala, peristiwa, atau kejadian yang terjadi pada saat sekarang. Dalam penelitian ini peneliti berusaha memotret peristiwa atau kejadian yang ada dalam karya sastra, kemudian digambarkan atau dilukiskan sebagaimana adanya.

Sumber data penelitian adalah novel Dari Fontenay ke Magallianes (DFM) karya Nh. Dini. Adapun data penelitian berwujud abstraksi yang diambil dari bahasa novel itu sendiri. Di samping itu ditunjang berbagai pemikiran penulis terkait dengan persoalan sosial dan kekuasaan. Data dikumpulkan melalui pembacaan yang intensif dan mencatat abstraksi-abstraksi yang mengindikasikan struktur, masalah sosial budaya, dan peristiwaperistiwa yang merupakan unsur cerita. Dengan demikian, instrumen utama penelitian adalah peneliti sendiri. Data diperoleh dari kutipankutipan novel Dari Fontenay ke Magallianes karya Nh. Dini. Hasil klasifikasi data digunakan penandaan seperti (DFM, 2005: 1) artinya Dari Fontenay ke Magallianes terbit tahun 2005, halaman 1). Penandaan tersebut akan digunakan dalam kegiatan analisis.

Analisis data penelitian ini menggunakan teknik (a) pemahaman arti secara mendalam menurut azas-azas hermeneutika, (b) analisis isi (content analysis) dan (c) analisis interaktif-dialektis atau bolak-balik sesuai dengan keperluan. Di samping itu juga, dilakukan penelaahan yang terkait dengan kerangka pikir pengarang dalam mendekonstruksi kekuasaan melalui narasi cerita. Analisis dilakukan secara melingkar, timbal balik, dalam rangka memperoleh pemahaman arti yang mendalam terhadap dekonstruksi kekuasaan dalam novel yang ditulis oleh Nh. Dini.

\section{HA S I L P N EL I T I A N D N PEMBAHASAN}

Pada pembahasan akan diuraikan berbagai hal terkait dengan dekonstruksi kekuasaan dalam novel Dari Fontenay ke Magallianes (DFM) karya Nh. Dini. Pembahasan lebih difokuskan pada aspek bentuk, fungsi, dan makna kekuasaan yang terdapat dalam novel NH. Dini. Hal ini disebabkan bahwa ketiga permasalahan tersebut memiliki andil yang cukup penting dalam mencermati berbagai bentuk kekuasaan yang terekspresi melalui karya sastra. Dengan demikian, akan diperoleh informasi yang komprehensif tentang bagaimana sebenarnya fenomena kekuasaan yang direfleksikan melalui karya sastra (teks sastra) itu dihadirkan oleh pengarang.

\section{Bentuk-bentuk Penggambaran Kekuasaan dalam novel Dari Fontenay ke Magallianes karya Nh. Dini}

Bentuk-bentuk kekuasaan yang tercermin pada novel Dari Fontenay ke Magallianes karya Nh. Dini lebih merefleksikan pada bagaimana Yves Coffin (sebagai suami) dalam berperilaku dengan anggota keluarga (Dini, Lintang, serta Padang) maupun teman-teman di tempat kerja. Bentuk kekuasaan dapat direduksi melalui sikap, ideologi, tingkah laku dalam merespons lingkungan yang menjadi bagian dari komunitasnya.

a. Dominasi

Dominasi dalam novel DFM dapat berupa peristiwa atau kejadian yang bersifat implisit maupun eksplisit dalam interaksi antartokoh dalam narasi cerita yang 
menunjukkan adanya penguasaan. Berikut ini beberapa contoh cuplikan peristiwa yang mengarah pada perilaku dominasi tokoh apabila berinteraksi atau berkomunikasikasi dengan tokoh yang lain.

Dalam hal pemutusan pemilihan kamar tokoh Yves, istrinya tidak pernah dimintai pertimbangan, sehingga sang isteri merasa tidak nyaman. Kutipan berikut memberikan dominasi Yves terhadap anggota keluarga.

Karena keterlaluan ingin menghemat, juga menurut prakiraan suamiku, kami akan segera menuju ke Prancis selatan maka kamar kami amat sempit. Aku merasa sangat tertekan berada di dalamnya. (DFM, $2005: 1)$.

Namun demikian, bagaimana karakter Yves yang begitu merasa menguasai segalanya sehingga orang lain harus dibatasi karena dirinya dianggap lebih penting ketimbang anggota keluarganya. Bagaimana tanggapan tokoh aku dalam memberikan komentarnya seperti terlihat pada kutipan berikut.

Suamiku mempunyai bagasi satu kopor pakaian, dua tas, dan satu kopor logam yang berisi alat-alat foto. Aku dan Lintang hanya 'berhak' membawa satu kopor dan dua tas tenteng kecil. Padahal semakin bertambah usianya, anakku semakin mempunyai kumpulan benda-benda dengan siapa dia merasa terikat. (DFM, $2005: 1$ )

Terkadang sifat laki-laki demikianlah, ada yang halus ada pula yang kasar, ada yang dermawan ada pula yang perhitungan dalam setiap pengeluaran untuk kepentingan keluarga. Seolah-olah dialah yang mengatur itu semua dan bahkan tidak jarang orang lain ataupun isterinya sendiri tidak dihargai. Perangainya yang kasar, menyakitkan hati dan suka menjengkelkan isteri. Hal ini dapat tampak pada kutipan berikut ini.

Kebalikan sikapnya yang selalu ringan tangan dalam membantu mencari air ayahnya Lintang tetap saja itungan. Sepekan sekali, para tamu wajib memberikan sejumlah uang sebagai umumnya untuk pengeluaran listrik dan belanja sembako. Tidak pernah terlewatkan satu hari Sabtu pun dimana suamiku diam, tidak menggerutu, langsung menggerutu, langsung mau memberikan uang kontribusi kepadaku atau kepada Mireille. Kutahan-tahan untuk tidak turut mengomel, menyesali sikapnya yang jelas tidak tahu berterima kasih kepada si empunya rumah (DFM, 2005 ; 12).

Begitu itulah lelaki pilihanku sendiri! Dia bicara asal bicara karena tidak mampu menahan nafsu mengeluarkan suara kasar, menyakitkan hati, atau menyinggung perasaan. Tapi kalau diingatkan supaya berpikir secara akal sehat, barulah dia sadar. Itupun jika si pengingat bukan relasi dekatnya, bukan isterinya. (DFM, 2005 ; 13)

Dengan perilaku suamiku yang pelit itu membuat diriku protes akan tetapi dia tinggallah diam tidak berbicara sama sekali. Ketika aku berbicara dia cenderung memiliki strategi diam tidak menanggapi barang sedikitpun. Demikianlah perilaku yang dia ekpresikan kepadaku.

Hanya saja uang saku dan uang belanja yang diberikan kepadaku tetap sangat dibatasi. Protes apapun yang kuajukan, pria pilihanku itu 'bertaktik' diam. Aneh juga! Dia yang serbasuka berbicara, kalau aku mengungkit masalah uang saku untukku, dia hanya diam. Berarti dia bisa nutup mulut kalau memang 'mau' (DFM, 2005 ; 32).

\section{b. Patriarkhi}

Dalam tradisi patriarkhal suami memiliki tugas mencari nafkah untuk keluarga sehingga ia selalu berperan di sektor publik. Dan sebaliknya, isteri (perempuan) selalu berperan dalam rumah tangga selayaknya ia menjalankan tugas-tugas domestik (kerumahtanggaan seperti: mengurus anak, memasak, membersihkan rumah, mendidik 
anak dan sebagainya, serta tugas lain yang berkaitan dengan tugas keperempuanan).

Dalam banyak hal tugas di luar rumah untuk mencari nafkah keluarga cenderung dilakukan oleh suami dan perempuan mengurus rumah tangga. Kesemuanya ini terefleksikan melalui tokoh cerita

Suaminya tinggal di Paris datang ke sana satu kali setiap dua pekan atau di saat kesempatan tersuguh. Dia seperti suamiku, harus berada di ibu kota untuk meraih tawaran terbaik bekerja di luar negeri. Kesempatan tersebut muncul sewaktu-waktu. (DFM, $2005: 8$ )

Bagaimana tokoh aku (perempuan) harus memerankan dirinya sebagai ibu rumah tangga yang baik dan menyiapkan kopi hangat untuk suami yang masih terlelap tidur dan bangun siang. Perempuan mempunyai tugas yang tidak dapat ditinggalkan untuk kepentingan suami dan anak-anak, misalnya: bagaimana ia harus menyiapkan sarapan, makan siang dan malam yang telah disepakati bersama. Kutipan peristiwa yang berkaitan dengan tugas-tugas perempuan tertera pada kutipan bagian berikut ini.

Dia adalah tamu yang paling siang meninggalkan tempat tidurnya. Mireille selalu menegurku bila kopi sudah dingin, harus segera dipanaskan, supaya selalu siap bila ayah anakku itu turun ke ruang makan. Dia adalah tamu yang paling siang meninggalkan tempat tidurnya. Mireille selalu menegurku bila kopi sudah dingin, harus segera dipanaskan, supaya selalu siap bila ayah anakku itu turun ke ruang makan. (DFM, 2005 ;9)

Aku menuruti anjuran temanku saja karena kupikir aku memang harus mengurusi suamiku. Dia sedang menikmati masa liburannya dan akan berangkat lagi ke Paris suatu hari nanti. Kewajibanku menyiapkan sarapan, makanan siang dan malam disesuaikan dengan persetujuan bersama-sama dengan teman yang lain. (DFM, 2005 ; 10)
Ketika ada acara rekreasi keluarga, tugas tokoh aku (isteri) menyiapkan segala perlengkapan yang dibutuhkan untuk kepentingan anak-anak. Hal ini sangat maklum bahwa para suami kurang memiliki kepedulian terhadap barangbarang yang harus dibawa ketika bepergian. Cuplikan peristiwa yang mendukung peristiwa tersebut adalah sebagai berikut.

Aku hanya berkewajiban menyiapkan tas berisi air, susu serta camilan anakku. Aku kurang mempercayai para suami itu akan ingat kebutuhan minum atau makan seorang anak berusia tiga setengah tahun. Juga kumasukkan baju rangkapan untuk siap sedia sekiranya cuaca mendadak menjadi terlalu sejuk. (DFM, 2005 ; 13-14)

Sebagai seorang isteri tokoh aku rela melakukan aktivitas rutin sebagai pendamping suami dan pengasuh anak-anak serta menjalankan tugas reproduksi untuk melanjutkan keturunan. Hidup ini ada masa yang menyenangkan dan tidak menyenangkan yang kesemuanya itu merupakan sebuah kewajaran. Hal ini dapat diperhatikan pada kutipan berikut.

Seperti di masa-masa lampau kutapakkan satu kaki di depan lainnya untuk meneruskan perjalanan umurku sebagai pendamping suami, pengasuh dan pemberi kasih sayang tanpa batas kepada anakku. Hingga kemudian, Tuhan melimpahkan karunia-Nya lagi kepadaku berupa bayi kedua. Dia terbentuk di rahimku tanpa kukehendaki. (DFM, 2005 ; 36)

Budaya patriakhi masih begitu kuat berada dalam kehidupan masyarakat Indonesia. Bagaimanapun budaya tersebut telah melekat demikian hebat sehingga sulit untuk dihapuskan. Terkadang untuk memberikan pemahaman pada keberadaan budaya tersebut masih terjadi pro dan kontra di antara masyarakat kita baik yang berpendidikan tinggi maupun pendidikan rendah. Demikian kuatnya budaya tersebut membingkai pemikiran 
individu sehingga segala sesuatunya seolaholah tidak dapat diubah. Cuplikan tersebut memberikan representasi kondisi cerita.

Kini Indonesia telah bebas dari penjajahan bangsa asing cerdik cendekia atau pengarang wanitanya justru terbelenggu karena sang uwak atau pihak penguasa di dalam keluarga tidak memberi izin manusia perempuan yang telah akil baliq itu untuk bepergian tanpa dikawal. (DFM, 2005 ; 19)

\section{c. Subordinasi}

Perempuan tersubordinasi oleh faktorfaktor yang dikonstruksikan secara sosial. Anggapan sementara bahwa perempuan itu irasional atau emosional, sehingga perempuan tidak dapat tampil memimpin, dan berakibat munculnya sikap yang menempatkan perempuan pada posisi yang tidak penting. Penempatan harkat dan martabat perempuan dalam posisinya sebagai individu kurang terperhatikan, bagaimana perempuan diumpamakan sebagai hewan yang menjadi barang kesukaan.

Dia tidak lagi dianggap sebagai isteri yang harus dihormati tapi justru malah dimarginalkan. Perilaku suami yang plin-plan membuat si isteri tidak lagi percaya kepadanya. Perubahan sikap karena posisinya yang lebih penting menyebabkan lelaki itu berubah total perilakunya terhadap isteri setelah melahirkan. Kutipan peristiwa dapat dicermati berikut ini

Tapi bagi kuda, burung perkutut, juga untuk wanita sangat tersebar luas di masyarakat. Seolah-olah perempuan sejajar dengan sejenis hewan tersebut ialah hanya sebagai barang kesenangan atau klangenan. Bukan sebagai garwa atau isteri yang biasa dihormatsemukan sebagai sigaraning nyawa. (DFM, $2005 ; 18)$

Selama dua tahun menjadi pendamping ayahnya Lintang; aku tidak yakin lagi apakah aku ini seorang perempuan yang pantas dicumbu, diperhatikan serta diberi kelembutan dan akhirnya dicintai. Sebegitu aku melahirkan, sifat ayah anakku berubah total. Seolah-olah aku telah menikahi lelaki lain, bukan yang pernah kukenal dan kugauli di Jakarta dulu. Baru dua tahun hidup bersama dia, rasa percaya diriku terkikis oleh perilaku kesehariannya yang serba plin-plan. (DFM, $2005: 15)$

Perilaku laki-laki yang menganggap bahwa perempuan sebagai pemuas nafsu belaka tidak akan hilang dalam pikirannya. Dia dapat memperlakukan perempuan seenaknya dan minta ditemani ketika bertugas berlayar. Ketika sedang membutuhkan pemenuhan biologis, dia tak segan-segan untuk meminta pada perempuan tersebut. Bagaimana tokoh aku merasa ngeri ketika suaminya bersama perempuan Jepang. Kutipan berikut memberikan representasi pada peristiwa yang dimaksud.

Kamu bagaimana? Selalu mengambil penumpang wanita sebagai pelampiasan kebutuhanmu? Atau di bawah, di darat?"

"Ketika aku muda, masih belum berpikir panjang belum menduduki jabatan penting ya di mana saja! Di mana ada kesempatan!" (DFM, 2005 ; 84)

Sebegitu Lintang lahir, sudah empat tahun sekarang, kau bikin aku menjauh darimu, karena sifat aslimu yang kasar dan pemarah membikinkungeri." kataku sambil menekankan kata 'ngeri' dan kalau kamu bisa melupakan kejadian di Himeji lalu di Motomachi bersama perempuan Jepang itu, aku masih ingat! Lalu di hotel di Phnom Penh! Aku akan selalu ingat itu semua. (DFM, 2005; 89)

Dari berbagai uraian yang telah dipaparkan di atas dapat dipahami bahwa bentuk-bentuk kekuasaan dapat dikritisi melalui pemikiran pascakolonialis. Pada peristiwa cerita tampak adanya pertentangan karakter tokoh dengan berbagai perilaku yang diekspresikan, baik secara eksplisit maupun 
implisit. Tokoh suami cenderung berpikir sesuai dengan pandangan dirinya sebagai lakilaki (Barat) yang harus menguasai segalanya, sedangkan tokoh perempuan cenderung melakukan tugas sebagai seorang isteri (ibu rumah tangga) yang identik dengan budaya timur. Di satu sisi ada keinginan tokoh perempuan memberontak terhadap peristiwa yang dialami meski disampaikan secara implisit.

\section{Fungsi Budaya Kekuasaan yang Diungkapkan dalam novel Dari Fontenayke Magallianes karya Nh. Dini}

Dari berbagai peristiwa bentuk-bentuk kekuasaan yang terjadi maka fungsi budaya kekuasaan adalah memberikan pengalaman kepada tokoh cerita. Persoalan-persoalan sosial yang harus ditanggung dengan perlakuan menyenangkan dan tidak menyenangkan harap dihadapi, diterima dengan perasaan suka maupun dan tidak suka. Namun demikian, karena cerita dijalin dengan baik kesan yang terjadi memberikan gambaran sosial yang terjadi pada masyarakat.

Kekuasaan telah memiliki ruang gerak yang cukup luas. Dia mampu menembus ke persoalan individu, keluarga, maupun komunitas sosial dalam arti luas. Namun, seolah-olah apa yang terjadi dalam refleksi kekuasaan merupakan sesuatu hal yang biasa dan tidak dianggap sebagai persoalan. Karakter budaya kekuasaan telah menyatu dengan kehidupan manusia. Di samping itu, karakter budaya kekuasaan berfungsi mengikat seseorang untuk tunduk dan mengikuti apa yang dikehendaki oleh mereka yang "berkuasa". Akan tetapi, orang lupa bahwa ketika ada aspek "pemaksaan" kepada seseorang untuk melakukan sesuatu, dapat berdampak kurang baik, seperti yang dialami oleh tokoh cerita tanpa adanya keharmonisan dalam keluarga.

Seperti halnya peristiwa yang terjadi pada novel Dari Fontenay ke Magallianes karya Nh. Dini, tokoh dengan berbagai karakter dan peran yang harus dibawakan benar-benar mengalami sebuah konstruksi budaya yang tak terelakkan. Apapun peristiwa yang dialami tokoh telah membawa karakter tokoh untuk mengikuti apa yang dikehendaki oleh kekuasaan itu. Ia tak berdaya untuk melakukan pembelaan atas apa yang terjadi pada dirinya. Bahkan, ia menerima apa adanya dan atau masa bodoh serta terkadang menggerutu atas apa yang terjadi dalam dirinya.

\section{Makna Dekontruksi Kekuasaan dalam Novel Dari Fontenay ke Magallianes karya Nh. Dini}

Pada dasarnya analisis pemaknaan yang dilakukan terhadap teks dan konteks merupakan wacana pengkonteran atas hegemoni pusat kekuasaan. Setelah dicermati pada novel Dari Fontenay ke Magallianes karya Nh Dini dapat dikatakan bahwa pusat kekuasaan ada di dua tokoh, yaitu laki-laki (suami) dan perempuan (isteri). Laki-laki cenderung berperilaku mendominasi atas tokoh cerita yang lain. Selanjutnya isteri merepresentasi kekuasaan yang terselubung. Kekuasaan yang terselubung itulah yang terkadang tidak dapat diketahui secara pasti oleh pihak tokoh laki-laki, misalnya ketika tokoh perempuan menjalin kasih dengan seorang kapten. Tampaknya terjadi dekonstruksi pada tokoh perempuan atas kekuasaan yang menimpa dirinya sehingga ia mampu melakukan counter hegemoni. Hal ini dapat dicermati melalui uraian berikut.

Pola pikir dan perilaku manusia selalu mengalami perubahan, termasuk yang dialami perempuan ketika dia berada pada kondisi yang kurang sesuai dengan harapan. Konstruksi lama bahwa perempuan sebagai makhluk yang lemah tidak selamanya dapat dibenarkan. Hal ini dapat diamati pada perilaku tokoh, bagaimana dia telah menaruh perhatian kepada seorang kapten (seseorang yang dulu pernah menaruh perhatian pada tokoh) dengan melakukan kemesraan di antara keduanya. Beberapa kutipan yang mengimplikasikan pada hal yang dimaksud adalah sebagai berikut.

Di Jepang kutitipkan anakku kepada Tante Un. Aku mendapat kesempatan luar biasa untuk 
berjalan-jalan ke beberapa kota wisata bersama Bagus, Kaptenku. (DFM, 2005 : 15)

Pria itu sudah menjadi bagian dari hidupku. Meskipun kelak kami akan lama tidak bertemu, dan tidak akan lepas dari diri dan batinku. (DFM, 2005: 16)

Bagi sebagian perempuan, perilaku sehari-hari lawan jenisnya merupakan dasar kenyamanan atau kekakuan pergaulan di ranjang. Bahkan bisa menjurus ke penolakan. Seperti diriku misalnya. Terus terang aku hanya bisa tidur dengan laki-laki yang penuh perhatian, peduli, dan maafBB-nya tidak terlalu menyengat.

Perokok dan peminum alkohol selalu kuhindari walau sifat lahiriyahnya menawan dan memikatku. (DFM, 2005 : 17)

Dan ketika Kapten mengundangku ke Marseille, temanku itu bersedia menjadi ibu asuh Lintang selama aku pergi. Aku berangkat menuju rendezvous. (DFM, $2005 ; 25)$

Pikiran tokoh perempuan setelah bertemu dengan kekasih lama mengalami perubahan. Ketika diperlakukan kasar oleh suaminya, dia tak segan-segan menolak melayani suaminya. Untuk melayani kebutuhan biologis suami, seorang isteri tidak ingin disamakan dengan pelacur. Suami secara diamdiam masuk ke kamar isterinya dengan cara mencuri kesempatan untuk dapat bersama isteri dengan cara-cara yang kurang baik. Namun, karena sifat suaminya kasar, dia menolak.

Mungkin dia sudah 'perkasa'. Barangkali dia memang sudah sehat. Tapi caranya memilikiku bagaikan pencuri, diam-diam masuk kamar selagi aku terlelap tidur, sangat menghinaku. Seandainya itu dilakukan oleh seorang lelaki yang memang mempunyai hubungan baik dengan pasangannya, yang 'biasa' saling setuju dan seia sekata, kelakuan tersebut justru dapat dianggap sebagai satu variasi atau imajinasi bercintaan. Tetapi dalam hal kami berdua, kukira karena dia mengerti betul bahwa aku pasti menolaknya, maka dia memanfaatkan keadaan. Hati usilku bahkan mempunyai praduga buruk: dia tidak mau menghabiskan uang untuk membayar pelacur guna memuaskan nafsunya, maka setelah merasa diri mampu berbuat, dia lampiaskan kepada istrinya, miliknya. Karena kekasarannyalah aku menolak (DFM, 2005; 101)

Suatu perilaku yang di luar dugaan suami bahwa si isteri telah melakukan kemesraan dengan seorang kapten (kekasih lama). Dia merasakan kepuasan terhadap orang yang telah memberikan perhatian, lembut, dan memiliki kekuatan untuk menggugah nafsu berahi tokoh isteri. Hal ini terasa jauh kemesraan yang terjadi apabila dibandingkan tokoh aku berhadapan dengan lelaki legal (suaminya). Bagaimana keberanian seorang perempuan menyerahkan tubuhnya untuk dapat dinikmati oleh orang yang dicintainya dan bahkan goresan-goresan yang ada dalam tubuhnya dia cermati karena dia merasa memiliki itu semua. Namun, bagaikan gayung bersambut, tokoh aku pun merasa ada kepuasan tersendiri setelah melakukan pemenuhan kebutuhan birahinya dengan orang yang dicintainya. Bahkan, dia berhak untuk menentukan dirinya siapa orang yang benarbenar dicintai dengan sepenuh hati, meskipun di satu sisi dia bukanlah lelaki yang dimiliki secara legal. Beberapa kutipan berikut memberikan reprensentasi peristiwa yang dialami tokoh cerita.

Seperti biasa, pada hari pertama kami kangenan, semua berlangsung dengan sangat cepat, kaku dan nyaris serba brutal. Bagaikan kehausan, kurasakan dan ingin segera memuaskan kebutuhannya. Demikian pula di pihakku. Sentuhan-sentuhan tergesa dari dia justru merangsang serta menggugah nafsuku. Ah, betapa bedanya akibat yang kurasakan jika itu datang dari lelaki legalku (DFM, 205: 116)

Akhirnya kami terengah-engah puas, tapi kerepotan karena masih berpakaian nyaris

Telaah Dekonstruksi Kekuasaan dalam Novel Dari Fontenay Ke Magalloanes... (Sugiarti) 
lengkap. Hanya tanpa sepatu, tanpa celana. Beberapa kali mengalami pertemuan kembali dengan cara begitu, aku mulai mengenal Kaptenku. Dan aku tidak berkeratan, menuruti saja. Apa pun yang dia perbuat terhadapku tidak kutolak. Ketika kami tenang kembali, dia membuka kancing-kancing bajuku. Aku membantunya, lalu ganti melepas pakaiannya. Setelah itu, kami baru saling berkabar. Sebentar-bentar dia meneliti bahuku, leherku, dia usap dia cium. Dia temukan beberapa goresan, keningnya berkerut, bertanya apa itu. Kujawab, itu hanya goresan buah bistru, karena ketika mandi, aku menggosokkannya ke badanku terlalu keras. Dia berbisik, "Hatihati! Jangan kaurusak kulitmu, karena aku juga turut memilikinya." (DFM, 2005: 116).

Tokoh aku telah melakukan keterbukaan hati kepada seorang kapten yang mengerti tentang dirinya. Dia menceritakan semua persoalan yang dialami bersama suaminya dan bahkan kejelekan suaminya. Tokoh aku yakin bahwa kapten yang menjadi dambaan hatinya itu mampu menyelesaikan berbagai persoalan yang dihadapinya. Bahkan, ketika akan menggugurkan kandungan tokoh aku menceritakannya. Suaminya yang suka membentak dan berteriak serta kecurigaan terhadap isterinya tentang uang belanja yang dia berikan semua telah diceritakan pada lelaki yang menjadi pujaan tokoh aku. Namun, yang terjadi bahwa kedua orang tersebut (tokoh aku dan lelaki pujaan) itu saling bercerita tentang kondisi/keadaan keluarga yang sama-sama tidak harmonis. Tokoh kapten merasa dirinya selalu dikekang oleh isterinya yang suka mengomel, sedikit marah dan pencemburu yang suka mengekang suami. Kedua-duanya berada dalam suasana keluarga yang tidak menyenangkan sehingga mereka mencari pelarian kepada orang lain yang memiliki perasaan yang sama untuk saling memahami.

Dekonstruksi kekuasaan yang terungkap dalam novel NH Dini lebih merepresentasikan tentang kondisi tokoh dalam konteks/situasi tertentu. Perlawanan budaya yang terjadi pada diri tokoh sebagai wujud bahwa tokoh perempuan pun mampu melakukan sebuah aktivitas atas kekuasaan yang dibangun melalui dirinya untuk melakukan bentuk kekuasaan "tandingan" yang terselubung maupun secara langsung. Nh. Dini mencoba untuk mendekonstruksi kekuasaan yang tidak hanya dapat dilakukan oleh laki-laki yang memiliki modal, pekerjaan, kekuatan, kekasaran dan sebagainya melainkan perempuan pun mampu melakukan sesuatu seperti yang dilakukan oleh laki-laki meskipun dengan cara yang berbeda. Dari sini dapat dikatakan bahwa makna kekuasaan telah mengalami dekonstruksi secara bertahap. Sebelumnya domain kekuasaan menjadi milik laki-laki sedangkan perempuan berada pada domain 'yang dikuasai'. Sekarang terjadi tawaran baru tentang dekonstruksi bahwa kekuasaan itu dapat menjadi milik tokoh lakilaki, ataupun perempuan dalam konteks cerita. Dengan perubahan dan perkembangan zaman yang terjadi dalam kehidupan manusia pada perkembangan pasca kolonialisme, berbagai pemikiran baru mulai bermunculan dengan berbagai argumentasi yang menyertainya.

\section{PENUTUP}

Berdasarkan uraian di atas dapat disimpulkan hal-hal sebagai berikut.

1. Bentuk-bentuk kekuasaan yang tercermin dalam novel DFM karya Nh Dini lebih merefleksikan pada bagaimana Yves (suami) dalam berperilaku dengan anggota keluarga (isteri dan anak-anak) maupun teman-teman di tempat kerja. Bentuk kekuasaan dapat direduksi melalui sikap, ideologi, tingkah laku tokoh dalam merespons lingkungan yang menjadi bagian dari komunitasnya. Bentuk-bentuk kekuasaan dapat berwujud dominasi, patriakhal, subordinasi. Sasaran kekuasaan tersebut ditujukan kepada tokoh perempuan.

2. Fungsi budaya kekuasaan dalam DFM karya Nh Dini adalah memberikan pemahaman bahwa berbagai persoalan sosial (kekuasaan) yang terjadi dalam kehidupan tidak mudah untuk diubah. Oleh 
karena itu, perlu bekerja keras untuk melakukan penataan atas hegemoni kekuasaan yang terjadi pada mausia yang seolah-olah dianggap sebagai sesuatu yang biasa.

3. Pemaknaan terhadap budaya kekuasaan yang diungkapkan dalam DFM karya Nh. Dini menunjukkan bahwa indikasi kekuasaan telah mengalami dekonstruksi secara bertahap. Sebelumnya, domain kekuasaan menjadi milik laki-laki, sedangkan perempuan berada pada domain 'yang dikuasai'. Sekarang terjadi tawaran baru tentang dekonstruksi bahwa kekuasaan itu dapat menjadi milik laki-laki ataupun perempuan dalam konteks cerita. Dengan perubahan dan perkembangan zaman yang terjadi dalam kehidupan manusia pada perkembangan pascakolonialisme berbagai pemikiran baru mulai bermunculan dengan berbagai argumentasi yang menyertainya.

\section{DAFTAR PUSTAKA}

Aminuddin.1987. Pengantar Apresiasi Karya Sastra. Bandung: Sinar Baru

Abdullah. 1997. Sangkan Paran Jender. Yogyakarta: Pustaka Pelajar.

Berger, dan Lukman. 1990. Tafsir Sosial atas Kenyataan. Jakarta: LP3ES

Berger, dan Berger. 1992. Pikiran Kembara: Modernisasi dan Kesadaran Manusia. Yogyakarta: Kanisius

Berten. 1983. Masalah "Dunia" dalam Filsafat Manusia. Jakarta: Gramedia

Budiman. 1981. Pembagian Kerja Secara Seksual. Jakarta: : Gramedia

Dini. 2005. Dari Fontenay ke Magallianes. Jakarta: Gramedia.
Damono. 2000. Sastra: Ideologi, Politik, dan Kekuasaan. Surakarta: UMS Press

Fakih. 1996. Menggeser Konsepsi Gender dan Transformasi Sosial. Yogyakarta: Pustaka Pelajar.

Faruk. 1994. Pengantar Sosiologi Sastra: Dari Strukturalisme Genetik Sampai Postodernisme. Yogyakarta: Pustaka Pelajar.

Kartodirdjo. 1992. Pendekatan Ilmu Sosial dalam Metode Sejarah. Jakarta: Gramedia.

Ratna. 2004. Teori, Metode dan Teknik Penelitian Sastra. Yogya-karta: Pustaka Pelajar.

Laurenson, dan Swingewood. 1972. The Sosiologi of Literature. London: Paladin

Ricouer. 1991. Reflection and Imagination: A Ricoeur Reader. New York: Harvester Wheatsheat.

Said. 2003. Kekuasaan, Politik, dan Kebudayaan. Pustaka Promethea

Satoto, Fananie (Ed.). 2000. Sastra, Ideologi Politik, dan Kekuasaan. Surakarta: Muhammadiyah University Press

Selden. 1993. Panduan Pembaca. Teori Sastra Masa Kini. (Diterjemahkan oleh Rahmat Djoko Pradopo). Yogyakarta: Gadjah Mada University Press.

Teeuw, A. 1984. Sastra dan Ilmu Sastra. Jakarta: Pustaka Pelajar.

Waluyo. 1992. Penelitian Pendidikan Bahasa dan Sastra. Surakarta : Sebelas Maret University Press

Wellek dan Warren. 1985. Teori Kesusastraan. Diterjemahkan oleh Melani Budianta. Jakarta: Gramedia. 